\title{
ПРИНЦИПИ ІНФЕКЦІЙНОГО КОНТРОЛЮ В МЕДСЕСТРИНСЬКІЙ ПРАКТИЦІ
}

\author{
о. Л. Дудкіна, Н. Б. Галіяш \\ Запорізька обласна дитяча клінічна лікарня \\ ДВНЗ «Тернопільський державний медичний університет \\ імені I. Я. Горбачевського МОЗ Украӥни»
}

У статті проаналізовано сучасні підходи до впровадження заходів інфекційного контролю у лікарняних закладах із метою профілактики внутрішньолікарняних інфекцій, вказано необхідні складові програм, які забезпечуватимуть кращий контроль внутрішньолікарняних інфекцій та будуть адаптованими до умов конкретного лікарняного закладу.

\section{PRINCIPLES OF INFECTION CONTROL IN NURSING PRACTICE}

\author{
O. L. Dudkina, N. B. Haliyash \\ Regional Zaporizhian Children's Hospital \\ I. Horbachevsky Ternopil State Medical University
}

In the article the modern approaches to the implementation of infection control measures in hospitals to prevent nosocomial infections were analyzed; we specified the essential components of programs that provide better control of nosocomial infections and are adapted to the conditions of specific health care setting.

Вступ. Значні досягнення сучасної медицини в галузі діагностики та лікування хвороб людини, в тому числі тих, що раніше вважалися невиліковними, зумовили підвищення рівня виживання хворих, але водночас створили певні проблеми, пов'язані з внутрішньолікарняними (госпітальними, нозокоміальними) інфекціями (ВЛІ), які в сучасний період набувають все більшого медичного та соціально-економічного значення [1]. Вони характеризуються тяжким клінічним перебігом, здатністю до ускладнення основного захворювання та високою летальністю, яка, за даними деяких авторів, становить при різних нозологічних формах від 14 до 58,6 \%, а в деяких випадках до 82,2 \% [1]. За даними ВОО3, показник летальності хворих із ВЛІ в 10 разів перевищує такий у пацієнтів без цієї інфекції. Значною проблемою $\epsilon$ також спалахи ВЛІ.

Широке розповсюдження ВЛІ в сучасний період відображено в багатьох наукових роботах, однак дані щодо рівнів ВЛІ суперечливі й залежать від країни, де проводилися дослідження, профілю стаціонару або відділення, ефективності та неупередженості системи реєстрації та інших об'єктивних і суб'єктивних причин. Особливо небезпечними ВЛІ $є$ для немовлят. У багатьох економічно розвинутих країнах світу ці

(с) Дудкіна, Н. Б. Галіяш, 2016 інфекції є одними з найчастіших ускладнень у новонароджених, особливо у відділеннях інтенсивної терапії акушерських стаціонарів, що зумовлено як складністю їх клініко-лабораторної діагностики, так і відсутністю стандартних ефективних методів лікування і профілактики [2].

Наукова медична громадськість вимушена визнати, що ера антибіотиків, яка почалась понад 70 років тому, призвела до непередбачуваних змін у розвитку класичного епідемічного процесу, насампереду лікарнях. Зазначимо, що лікувально-профілактичні заклади - це специфічні об'єкти, де концентруються хворі - люди з ослабленою імунною системою, яким проводиться значна кількість інвазивних діагностичних і лікувальних процедур, а отже мають місце всі умови (джерела, множинність факторів передачі, сприйнятливі організми) для формування і розповсюдження госпітальних штамів мікроорганізмів, яким притаманна, як правило, множинна стійкість до антибіотиків і здатність швидко пристосовуватись до несприятливих факторів [2, 3]. «Традиційний пейзаж» мікроорганізмів - збудників найбільш поширених гнійно-запальних захворювань сьогодні набув принципово іншого вигляду, значно урізноманітнився за рахунок умовно-патогенних або навіть сапрофітних видів мікробів. 
Основна частина. В Україні в умовах сьогодення критична ситуація з ВЛІ ускладнюється також через довготривалу і болісну трансформацію всієї системи медичної допомоги та традиційного браку коштів для достатнього рівня утримання муніципальних лікувальних закладів [1]. Загроза невпинного розповсюдження ВЛІ посилюється цілим рядом факторів, серед яких ми маємо відзначити збільшення кількості багатопрофільних лікувальних установ, створення нових видів медичного інструментарію, приладів, лікувальних препаратів, впровадження нових видів інвазивних (інструментальних) діагностичних та лікувальних втручань, збільшення кількості хворих із пригніченим імунітетом, несприятливі соціальноекономічні умови для більшості населення.

Сумні наслідки ВЛІ можна сформулювати однією фразою: людина, яка звернулася у медичний заклад за допомогою, замість неї може отримати нове, часто більш тяжке та небезпечне захворювання, подолання якого потребує більше коштів, часу, фізичних та психічних ресурсів пацієнта. Саме існування ВЛІ, як госпітального феномену, перекреслює головний принцип медицини «no nocere» - «не нашкодь» та ставить під сумнів головне призначення лікарняного закладу - лікування хворого. За таких умов дуже важливим $є$ впровадження комплексу заходів, що без значних фінансових витрат змогли б істотно знизити розповсюдженість ВЛІ [3, 4]. В основу програм боротьби з ВЛІ покладено важливе теоретичне положення щодо необхідності використання специфічної сукупності прийомів вивчення епідемічного процесу ВЛІ, адаптованих до клінічних умов. На підставі цього для забезпечення епідеміологічної безпеки встановлюються вимоги до лікувально-діагностичного процесу та умов, в яких він здійснюється. В цьому полягає стратегія підвищення якості медичної допомоги через впровадження в практику охорони здоров'я системи інфекційного контролю, успішність якої на сьогодні доведено досвідом багатьох країн світу. В різних країнах існують різні програми інфекційного контролю, спектр яких залежить від багатьох факторів, включаючи соціально-економічну ситуацію, медичні традиції тощо. Світовий досвід свідчить, що впровадженням інфекційного контролю можна запобігти до третини випадків госпітальних інфекцій [2, 3].

Сам термін «інфекційний контроль» (ІК) визначається як комплекс ефективних організаційних, профілактичних та протиепідемічних заходів, спрямованих на попередження виникнення та розповсюдження внутрішньолікарняних інфекцій, що базується на результатах епідеміологічної діагностики. В цьому визначенні відображено принципову відмінність стратегії боротьби з внутрішньолікарняними інфекціями на основі визнаної у багатьох країнах системи інфекційного контролю від діючої дотепер в Україні стратегії регулюючих заходів, які передбачено у раніше розроблених нормативних документах.

Донедавна традиційні для нашої країни регулюючі заходи передбачали абсолютний диктат зовнішніх контролюючих організацій та нормативних документів, порівняння даних про випадки ВЛІ із зовнішніми стандартами, інспективний характер відношень 3 окремими ЛПЗ, покарання за недотримання зовнішніх стандартів. На відміну від них впровадження системи інфекційного контролю переносить головний напрямок боротьби із ВЛІ до кожного конкретного стаціонару, де за умов постійної спрямованості на поліпшення та навчання принципам інфекційного контролю, персонал сам ставить мету та визначає методи її досягнення, постійно збирає дані для внутрішньої оцінки стану відносно внутрішньолікарняних інфекцій, а недоліки розцінюються як вади впровадженої у даному стаціонарі системи інфекційного контролю, а не конкретної особи. Тільки такий підхід може сприяти пошуку шляхів поліпшення епідемічної ситуації в кожному конкретному стаціонарі та в країні в цілому $[2,4]$.

У кожній країні, з урахуванням її економічних, соціальних, культурних особливостей розробляються свої базові національні програми інфекційного контролю, які можуть бути адаптовані до умов конкретного лікарняного закладу з урахуванням особливостей стаціонару і можливостей мікробіологічної лабораторії [4]. В такому розумінні система, саме система, інфекційного контролю, не вміщує суворо обумовлених кроків (наказ, припис), а має клінічне спрямування і ставить за кінцеву мету поліпшення якості лікувального процесу. У цьому сенсі інфекційний контроль не ототожнюється із протиепідемічним режимом, який $\epsilon$ хоч і необхідною, але лише складовою частиною системи. Річ у тому, що протиепідемічний режим забезпечує захист переважно від розповсюдження в стаціонарах класичних патогенних збудників, але на їх долю припадає лише незначна доля збудників ВЛІ. Левова частка в етіологічній структурі ВЛІ належить умовно-патогенним мікроорганізмам, що зумовлено факторами лікувально-діагностичного процесу та специфікою контингенту хворих. 3 цього випливає 
надзвичайно важливе положення: певна частина ВЛІ $\epsilon$ невідворотною, а зусилля мають бути спрямовані на випадки, які можна попередити. Таким чином, інфекційний контроль в лікувально-профілактичному закладі визначається як система постійного епідеміологічного спостереження з епідеміологічним аналізом результатів цього спостереження та проведення на підставі епідеміологічної діагностики цілеспрямованих заходів щодо підвищення якості медичної допомоги [1]. Метою інфекційного контролю $є$ зниження захворюваності, летальності та економічних збитків від госпітальних інфекцій. Окрім цього, в стаціонарах названа система повинна забезпечити покращення якості медичної допомоги та забезпечити захист здоров'я персоналу [3].

Програма інфекційного контролю будь-якого рівня повинна включати [1]:

- організаційну структуру управління системою IK;

- епідеміологічний нагляд;

- мікробіологічний моніторинг;

- комплекс профілактичних та протиепідемічних заходів;

- заходи, спрямовані на охорону здоров'я медичного персоналу;

- систему навчання медичного персоналу.

Національна програма інфекційного контролю передбачає зміни в організаційній структурі лпу, зокрема впровадження посади госпітального епідеміолога, який має бути однією з центральних фігур у розробці й реалізації програм інфекційного контролю. «Робоче місце» госпітального епідеміолога - це умовний центр, де накопичуються з усіх відділень стаціонару достовірні дані про кількість хворих на гнійно-запальні захворювання та про особливості лікувально-діагностичного процесу, з бактеріологічної лабораторії - дані про мікроорганізми, що циркулюють у відділеннях стаціонару та їх антибіотикостійкість. Госпітальний епідеміолог повинен мати технічні можливості та вміти проводити аналіз отриманих даних, розробити алгоритми доведення результатів аналізу до медичних працівників, територіальної санітарно-епідеміологічної служби та до діючої комісії (комітету) з інфекційного контролю свого лікувального закладу. Остання на підставі представлених даних приймає управлінські рішення. Позитивним на сьогодні $\epsilon$ те, що посада госпітального епідеміолога вже передбачена діючими нормативними документами, визначено його статус та зміст функціональних обов'язків у стаціонарі.
Добре організований епідеміологічний нагляд, який включає всі вищевказані елементи і мікробіологічне моніторування циркуляції збудників госпітальних інфекцій, забезпечує високу ефективність епідеміологічної діагностики, що $є$ абсолютно необхідним для управління епідемічним процесом ВЛІ [4]. Епідеміологічний нагляд дозволяє знизити рівень захворюваності на внутрішньолікарняні інфекції вже на першому етапі свого впровадження.

Невід'ємною частиною інфекційного контролю $\epsilon$ також мікробіологічний моніторинг. Для динамічного спостереження за структурою і рівнем стійкості мікроорганізмів до антимікробних препаратів рекомендована комп'ютерна програма WHONET, яка отримала схвальну оцінку ВОO3 $[1,6]$. Остання версія WHONET використовується в Західній та Східній Європі, США, Канаді, країнах Азії; а за отриманими даними видається спеціальний бюлетень WHONETnews, який дозволяє клінічним мікробіологам та госпітальним епідеміологам усього світу координувати свою діяльність, обмінюватися досвідом роботи з програмою та містить методичні рекомендації щодо використання WHONET для вирішення окремих задач.

Дані мікробіологічного моніторингу (видовий спектр збудників ВЛІ, колонізуючих агентів, антибіотикорезистентність та ії профілі із зазначенням діаметрів зон затримки росту виділених мікроорганізмів навколо дисків з антибіотиками) збираються і аналізуються госпітальним епідеміологом, щомісяця розглядаються на засіданні комісії інфекційного контролю (КІК) і доводяться до відома всіх співробітників стаціонару $[1,3]$. Мікробіологічний моніторинг $\epsilon$ підставою для контрольованого призначення антибактеріальних препаратів для емпіричної антибіотикотерапії й періоперативної антибіотикопрофілактики [5]. Це також дає змогу запобігти використанню в конкретному стаціонарі антибіотиків, до яких у 25 \% і більше циркулюючих штамів виявлена антибіотикорезистентність. Отже, із впровадженням у практичну діяльність програми WHONET у лікарів виникає можливість призначати антибіотики не тільки після визначення чутливості до лікарського препарату мікроорганізму, виділеного з біологічного матеріалу конкретного пацієнта, але й на підставі моніторингу та аналізу раніше отриманих результатів бактеріологічних досліджень та визначення антибіотикорезистентності. За рахунок зменшення витрат на придбання медикаментів, лікування ускладнень, скорочення строків перебування пацієнтів у стаціонарі це значно підвищує ефектив- 
ність медичної допомоги. Перевагою комп'ютерної програми WHONET $є$ й те, що її впровадження не потребує значних фінансових витрат (необхідно лише обладнати робоче місце госпітального епідеміолога персональним комп'ютером та встановити програмний продукт, розміщений в мережі «Інтернет»).

Ще одним із компонентів національної програми інфекційного контролює комплекс профілактичних та протиепідемічних заходів, який передбачає [5, 7]:

- оптимізацію заходів боротьби і профілактики ВЛІ з різними шляхами передачі збудника;

- раціоналізацію основних принципів госпітальної гігієни, зокрема впровадження заходів, які можна охарактеризувати в цілому як «чисті руки»;

\section{ЛITEPATУРA}

1. Профілактика внутрішньолікарняних інфекцій (гігієнічні, епідеміологічні та мікробіологічні аспекти) : навч. посіб. / О. А. Шевченко, С. І. Гаркавий, Е. А. Деркачов [та ін.] ; за ред. В. Ф. Москаленка. - К., Дніпропетровськ, 2012. - 182 c.

2. Внутрибольничные инфекции / под. ред. В. П. Венцева. - М. : Медицина, 1990. - 655 с.

3. Таран В. В. Аналіз захворюваності на внутрішньолікарняні інфекції у лікувально-профілактичних закладах України / В. В. Таран // Науковий вісник міжнародного гуманітарного університету. - 2014. - № 8. - С. 43-48.

4. Національна доповідь про стан техногенної та природної безпеки в Україні у 2013 році [Електронний
- підвищення ефективності дезінфекційних та стерилізаційних заходів, максимально високий рівень застосування одноразового медичного інструментарію та обладнання, епідемічно безпечну утилізацію медичних відходів;

- економічну оцінку системи профілактики ВЛІ.

Висновок. У програмі інфекційного контролю необхідно ретельно прописувати заходи мікробіологічного моніторингу, комплекс профілактичних та протиепідемічних заходів, заходи, спрямовані на охорону здоров'я та систему навчання медичного персоналу.

ресурс]. - Режим доступу : http://www.mns.gov.ua/files/ prognoz/report/2013/3_4.pdf

5. Про організацію контролю та профілактики післяопераційних гнійно-запальних інфекцій, спричинених мікроорганізмами, резистентними до дії антимікробних препаратів : наказ МОЗ України № 236 від 04.04.2012.

6. Матеріали 10-го міжнародного конгресу з інфекційного контролю (IFIC), 8-11 жовтня 2009 р., Вільнюс, Литва.

7. Профілактика внутрішньолікарняних інфекцій : рішення спільної розширеної колегії МОЗ та Державної санітарно-епідеміологічної служби України від 03.09.04.

Отримано 15.04.16 